\title{
Ultimate and Proximate Analysis of Coal Samples from Different Regions in Pakistan for their Future Utilization Muhammad Saeed Ullah $^{1^{*}}$, Umair Zahid ${ }^{1}$ and Tariq Masood ${ }^{2}$
} Affiliation

${ }^{1}$ Institute of Chemical Engineering and Technology, University of the Punjab, Lahore, Pakistan

${ }^{2}$ Department of Process Operations and Control Systems Engineering, University of Bath, Bath, United Kingdom

*Corresponding author: Muhammad Saeed Ullah, Institute of Chemical Engineering \& Technology, University of the Punjab, Lahore, Pakistan, Email: engrsaeed147@gmail.com

Citation: Ullah SM, Zahid U and Masood T. Ultimate and proximate analysis of coal samples from different regions in Pakistan for their future utilization (2019) J of Heterocyclics 1: 39-41.

Received: Oct 21, 2019

Accepted: Nov 11, 2019

Published: Nov 18, 2019

Copyright: () 2019 Ullah SM, et al., This is an open-access article distributed under the terms of the Creative Commons Attribution License, which permits unrestricted use, distribution, and reproduction in any medium, provided the original author and source are cre dited.

\section{Abstract}

A comparison of coal samples obtained from various regions of Pakistan was done based on their proximate and ultimate analysis and gross calorific values to discern the processing technique which may be applied for these coals e.g. liquefaction, gasification, carbonization etc. The samples of coal were got from different coal fields in Pakistan. Different nomenclature were chosen to differentiate the regions of coal e.g., SRGE for coal obtained from Sor-Range and Degari coalfields near Quetta, Baluchistan, LKR for coal obtained from Lakhra, Sindh, SLGE for coal obtained from Salt Range coalfields near Chakwal, Punjab, KTL for coal obtained from Kotli, Azad Jammu Kashmir (AJK), MCH for coal obtained from Mach, Baluchistan and THR for coal sample obtained from Tharparkar, Sindh. MCH coals were reported with highest calorific value of $13305.35 \mathrm{kcal} / \mathrm{kg}$. THR coals were classified as class (2) coals as they were found with calorific values \& carbon contents of 12337.13 $\mathrm{kcal} / \mathrm{kg}$ and $69.9 \%$ respectively. KTL coal samples were reported with lowest carbon contents of $57.9 \%$ in ultimate analysis experiments. MCH \& SRG coals were nominated as low quality coals because of their highest ash contents i.e., 50\%. SRGE and SLG coals were found hazardous for our ecosystem because of their high sulfur contents. SRGE, LKR, SLG and THR were classified as class (2) bituminous coals and were found best gas coals, while MCH and KTL were found class (1) and class (4) bituminous coals respectively.

Keywords: Characterization of Coal, Processing of Coal, Proximate and Ultimate Analysis of Coal, Potential Utilization.

Abbreviations: SRGE- Sor range and Degari, SLGE- Salt range, LKR-Lakhra, KTL- Kotri, MCH- Mach, THR- Tharparkar
\end{abstract}

\section{Introduction}

Fossil fuels like coal, petroleum and natural gas are nonrenewable sources of energy. They were formed from plants and animals remain (millions of years ago) and their deposits are found beneath the earth. For this modern society the demand of energy is increasing day by day. Fossil fuels are the main source to meet our $85 \%$ of total demand of energy. Coal is supposed to recoup its position as a major energy source. Basically coal is segregated into four major classes; lignite, sub-bituminous, bituminous and anthracite [1,2].

Coal is combustible and carbonaceous solid that is obtained by decomposition of plants because of pressure, temperature and compact force. We can differentiate the types of coal from high rank to low rank according to their colors from brown to black respectively. The source of vegetation contains from low plant forms i.e., moss to significant woody plant precursors. Although the heating value is provided by the carbon contents of coal, however the other factors such as moisture contents, ash contents and sulfur contents play an important role for defining the rank for a particular source of coal. The top ranked coal is anthracite with highest contents of carbon e.g., 86-98\% and having a calorific value of ranges from 22-28 million BTU/ton. It contains low percentage of volatile elements and is used for commercial and residual purposes. Bituminous and Sub-bituminous coals have calorific values of ranges from 20-30 million BTU/ton and 17-23.5 million Btu/ton Respectively. These coals are present in dark
To dark brown colors and are commonly utilized as a fuel for energy generation \& metallurgical Purpose. The lowest rank of coal is lignite with brown color; it is solely used as fuel for electricity generation. Lignite coals have calorific values ranges from 9 to 17 million $\mathrm{Btu} /$ ton [3].

In late 18 th century coal was commercially used by the north-western railways during colonial regime after uncovering of coal in Balochistan area which is now a province of Pakistan. At present total coal reserves of Pakistan are estimated about 184.5 billion tons including newly discovered deposits of Thar coal having lower contents of sulfur. Various minerals are associated with the composition of coal; the combustion of coal produces notable amounts of solid residues such as fly ash. While transportation or disposal operations these wastes are come into contact with water leading to leaching out the various toxic elements such as nickel, lead, cadmium, zinc, chromium and mercury from the ashes which contaminate the ground water and soil. While the other inorganic constituents such as potassium, sodium and zirconium associated with minerals are present in trace amounts in coal [4,5].

In various environmental substances like soil, air and water, different amounts of both necessary and toxic metals are available. The real amounts of these metals in living bodies depends on various factors such as the actual concentration in that area, the food pattern, industrial

Citation: Ullah SM, Zahid U and Masood T. Ultimate and proximate analysis of coal samples from different regions in pakistan for their future utilization (2019) J of Heterocyclics 1: 39-41. 
circumstances and the most common profession of the people of that area $[6,7]$.

The combustion of coal as a fuel emits various toxic elements such as $\mathrm{CO}_{2}, \mathrm{SO}_{\mathrm{x}}, \mathrm{NO}_{\mathrm{x}}$ and some volatile inorganic elements (especially As, $\mathrm{Be}, \mathrm{Cd}, \mathrm{Co}, \mathrm{Cr}, \mathrm{Hg}, \mathrm{Mn}, \mathrm{Ni}, \mathrm{Pb}, \mathrm{Sb}, \mathrm{Se}$ ) and their compounds in flu gas. These emissions may have critical effects on our eco system like globally increase in temperature and head-on hazards to agricultural lands, water and human health. There are also various types of land pollutions like inorganic constituents in fly ash, bottom and slag disposed. After releasing into the environment these pollutants may lead to various chemical reactions which may transform them into different hazardous compounds. To investigate the presence of these inorganic elements in coal samples, Atomic Absorption Spectrophotometric Analysis was used particularly although there are large reserves of coal in Pakistan, but there is an essential need to be utilized for development of country. Sindh province is the richest region of Pakistan with respect to coal reserves e.g., 175 billion tons of lignite coal is located in Thar region of Sindh. Pakistan is world's 7th country in having reserves of lignite coal. It is estimated that Thar coal has a great potential for electricity production such as 100,000 MW at consumption of 536 million tons per year. Although Thar coal has lowest sulfur content, still it needs to be developed for mining and generation of energy because of economical and environmental aspects [8-11].

Additionally to Thar coal reserves, there are lignite coal reserves located in various regions of Pakistan i.e., Sonda Indus East, Lakhra and other areas of Sindh. Bituminous and good quality sub-bituminous coals can be utilized for electricity generation and their reserves in large amounts are located in different coalfields of Punjab and Baluchistan provinces of Pakistan. Other coal reserves available in KPK and AJK regions of Pakistan are being mined in smaller amounts. As Pakistan is importing coal for its steel, cement and power industry on a large scale from Indonesia, Afghanistan and other countries, these expenditure can be saved and utilized for research and development purposes if we will develop feasible and useful process to utilize our local coal . It is essential to develop local coal reserves in Pakistan as demand for energy is increasing day by day due to the population increase and modernization of the world. There is an inevitable demand to define the feasible and environmental friendly methods of utilizing the local coal reserves. In this research article addition to compare the environmental impacts of coal samples from various regions of Pakistan, the proximate and ultimate analysis were done to characterize the samples and to investigate their industrial applications $[12,13]$.

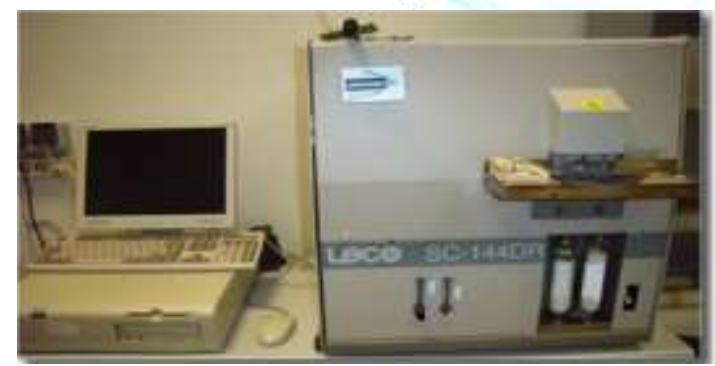

Figure 1: LECO SC-144DR Sulphur-Carbon Analyzer

\section{Materials and Method}

Six coal samples were obtained in the form of lumps; their sizes were in ranges from 400-500 grams per piece. In order to obtain the required size of coal samples for determination of calorific value, Ultimate and Proximate analysis, and coal samples were crushed down using a hammer following pulverization of crushed coals separately in an end runner mill until a size of -72 B.S mesh. To avoid cross contamination due to finer size of samples, various preventive steps have been followed. After each sample every sieve was cleaned with water and dried over a gas heater. In the same manner the bowl and pestle of end runner mill was cleaned using a wet cloth after using for each sample.
All of the six samples were stored in a cool and dry place after pouring them into air tight Ziploc bags in order to prevent from any excessive moisture contents. The most commonly used method for analysing the coal samples is proximate analysis in which volatile matter, moisture contents, ash contents and fixed carbon are determined. The quality and rank of coal are assessed generally by proximate analysis. Using bomb calorimeter calorimetric analysis was performed to determine the energy exchange between the reaction system and the environment. Elemental analysis also called ultimate analysis is used to design the coal burning equipment and auxiliaries. Usually weight percentages of carbon, nitrogen, hydrogen, oxygen and sulfur are determined in ultimate analysis. Due to unavailability of analysis equipment, in this research study only sulfur and carbon contents in each sample were determined using a LESCO SC-144DR analyzer following ASTM $5016-08$ method. This analysis starts as a sample $(0.350 \mathrm{gm}$ nominal $)$ is weighed into a combustion boat. The sample within the combustion boat is placed in a pure oxygen environment typically regulated at 1350 ${ }^{\circ} \mathrm{C}$, and then undergoes complete combustion, releasing the sample's carbon as carbon dioxide gas and sulphur as sulphur dioxide.

The sample's combustion gases are first swept through the boat stop to the back on the inner combustion tube, then forward between the inner and outer tubes, allowing the combustion gases to remain in the high temperature zone for a longer period and permit efficient oxidation. From the combustion system, the gases flow through two anhydrous tubes removing moisture, through a flow controller that set the flow of the combustion gases through the infrared detection cell. The carbon IR cell measures the concentration of carbon dioxide gas. The sulphur IR cell measures the concentration of sulphur dioxide gas. The LECO SC144DR analyzer is controlled by an external PC using a windowsbased operating system.

\section{Results}

Calorimetry of the coals

Calorimetry results were performed and $\mathrm{MCH}$ coals were found with maximum calorific values i.e., $13305.35 \mathrm{kcal} / \mathrm{kg}$. THAR coals were also found with comparable calorific value while the lowest value was determined for SLG coal samples.

\begin{tabular}{|c|c|c|c|c|c|}
\hline $\begin{array}{c}\text { Coal } \\
\text { Sample }\end{array}$ & $\begin{array}{c}\text { Sample } \\
\text { Weight } \\
(\text { grams })\end{array}$ & $\begin{array}{c}\text { Initial } \\
\text { Temp } \\
\left({ }^{\circ} \mathbf{C}\right)\end{array}$ & $\begin{array}{c}\text { Final } \\
\text { Temp } \\
\left({ }^{\circ} \mathbf{C}\right)\end{array}$ & $\begin{array}{c}\text { Temp } \\
\text { Rise } \\
\left({ }^{\circ} \mathbf{C}\right)\end{array}$ & $\begin{array}{c}\text { GCV } \\
(\mathbf{k c a l} / \mathbf{k g})\end{array}$ \\
\hline SRGE & 1.58 & 25.4 & 27.3 & 1.9 & 8772.462 \\
\hline LKR & 1.06 & 26.8 & 28.2 & 1.4 & 9634.906 \\
\hline SLG & 1.55 & 24.4 & 25.8 & 1.4 & 6589.032 \\
\hline KTL & 1.58 & 22.3 & 24.8 & 2.5 & 11542.72 \\
\hline MCH & 1.59 & 19.8 & 22.7 & 2.9 & 13305.35 \\
\hline THR & 1.36 & 18.4 & 20.7 & 2.3 & 12337.13 \\
\hline
\end{tabular}

Table 1: The results of the Calorimetry of the coal.

Proximate analysis of the coals: Proximate analysis of all coal samples was performed. The maximum carbon contents were found in THAR coal samples while the lowest carbon contents were investigated for SRG coals. MCH \& SRG coals were nominated as low quality coals because of their highest ash contents i.e., $50 \%$.

Ultimate analysis of the coals: The results of ultimate analysis have shown that SRG and SLG coals are not suitable to use them as fuel because of their without sulfur removal as they contain high percentage of sulfur i.e., $4.9 \%$.THR coals were found best because they contain less sulfur contents and highest carbon contents. Lowest carbon contents were found in KTL coal samples that were $57.9 \%$.

\section{Discussion}

According to the standard table suggested by Regnault-Grüner-Brosquet (table 4), coal samples were classified. SRG, LKR, SLG and THR are bituminous class (2) coals which yields $32-40 \%$ volatile matter and a porous coke of moderate strength at $900^{\circ} \mathrm{C}$. While $\mathrm{MCH}$ is a bituminous coal of class-1. It is a Super bituminous coal that yields at $900^{\circ} \mathrm{C}$ more than $40 \%$ of volatile matter and a non-coherent carbonaceous residue. Although 
KTL is a class (4) coal as its volatile matter content is $16 \%$ but its moisture content is the lowest out of the six samples i.e. 4\% [14].

\begin{tabular}{|c|c|c|c|c|}
\hline $\begin{array}{c}\text { Coal } \\
\text { Sample }\end{array}$ & $\begin{array}{c}\text { Moisture } \\
\text { Content } \\
(\%)\end{array}$ & $\begin{array}{c}\text { Volatile } \\
\text { Matter } \\
(\%)\end{array}$ & $\begin{array}{c}\text { Ash } \\
\text { Content } \\
(\%)\end{array}$ & $\begin{array}{c}\text { Fixed } \\
\text { Carbon } \\
(\%)\end{array}$ \\
\hline SRGE & 9 & 38 & 50 & 3 \\
\hline LKR & 8.58 & 36.24 & 34.83 & 20.35 \\
\hline SLG & 7 & 32 & 50 & 11 \\
\hline KTL & 4 & 16 & 36 & 44 \\
\hline MCH & 6.5 & 42 & 39.5 & 12 \\
\hline THR & 29.9 & 35.4 & 4.9 & 29.8 \\
\hline
\end{tabular}

Table 2: The results of the proximate analysis of the coal.

\begin{tabular}{|c|c|c|c|}
\hline $\begin{array}{c}\text { Coal } \\
\text { Sample }\end{array}$ & $\begin{array}{c}\text { Total } \\
\text { Sulfur }(\%)\end{array}$ & $\begin{array}{c}\text { Total } \\
\text { Carbon }(\boldsymbol{\%})\end{array}$ & $\begin{array}{c}\text { Total } \\
(\mathbf{H}+\mathbf{N}+\mathbf{O})(\boldsymbol{)})\end{array}$ \\
\hline SRGE & 4.9 & 61.9 & 33.2 \\
\hline LKR & 3.01 & 70.8 & 26.19 \\
\hline SLG & 4.9 & 60.4 & 34.7 \\
\hline KTL & 3.6 & 57.9 & 38.5 \\
\hline MCH & 4.2 & 78.1 & 17.7 \\
\hline THR & 1.9 & 69.9 & 28.2 \\
\hline
\end{tabular}

Table 3: The results of the ultimate analysis of the coal.

\begin{tabular}{|c|c|c|c|c|c|c|c|c|}
\hline \multirow{2}{*}{ Genus } & \multirow{2}{*}{ Class } & \multirow{2}{*}{ Chief Uses } & \multicolumn{3}{|c|}{ Percentage Composition } & \multirow{2}{*}{$\begin{array}{c}\% \text { volatile } \\
900^{\circ} \mathrm{C}\end{array}$} & \multirow{2}{*}{$\begin{array}{l}\text { \% Fixed } \\
\text { carbon }\end{array}$} & \multirow{2}{*}{$\begin{array}{c}\text { Character of } \\
\text { carbonaceous residue }\end{array}$} \\
\hline & & & $\mathbf{C}$ & $\mathbf{H}$ & $\mathrm{O}+\mathrm{N}+\mathrm{S}$ & & & \\
\hline \multirow{4}{*}{ 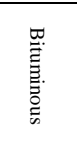 } & 1) Noncaking Long flame & Reverberatory furnace & $75-80$ & $4.5-5.5$ & $15-20$ & $40-45$ & $55-60$ & Non Coherent \\
\hline & 2) Caking Long Flame & Gas making & $80-85$ & About 5.6 & $10-15$ & $32-40$ & $60-68$ & Very porous coke \\
\hline & 3) Hard caking & Coke manufacture & $84-89$ & $5-5.6$ & $5.5-11$ & $26-32$ & $68-74$ & Dense coke \\
\hline & $\begin{array}{l}\text { 4) Hard caking, short } \\
\text { flame }\end{array}$ & $\begin{array}{l}\text { Coke manufacture } \& \\
\text { steam raising }\end{array}$ & $88-90$ & $4.5-5.5$ & $5.5-6.5$ & $16-26$ & $74-82$ & Very dense coke \\
\hline
\end{tabular}

\section{Conclusion}

Table 4: Classification of coal (Regnault-Grüner-Brosquet Standard Tab.

From the above discussion it was concluded that SRG, LKR, SLG and THR are bituminous class (2) coals. These coals are the best gas-coals. They burn with a long luminous flame, and on distillation pass through a stage of intumescences, during which gas is freely expelled. Although THR coal has the lowest sulphur contents i.e. 1.9\%, still there is a need to remove sulphur contents by Claus's process during a stage in coal liquefaction. $\mathrm{MCH}$ being a class (1) bituminous coals burn with a very long and highly luminous smoky flame and for that reason are chiefly valued for the firing of reverberator furnaces and the like. They are also used to some extent as house coals, because of their free burning qualities. They are not, however, good for steam rising, and their non-caking character renders them quite useless for coke manufacture. KTL are class (4) bituminous coals \& having low moisture contents i.e. 4\%. Coal gasification requires low moisture content of coal; KTL may be used for this process as its moisture content is the lowest out of the 6 samples. They are caking coals and therefore, they may be used in carbonization.

\section{References}

1. Saeed K, Ishaq M, Ahmad I and Park SY. Characterization and evaluation of Thar coal for different mineral contents (2006) Journal Chem Society Pakistan 28: 207-210.

2. Satti SL, Hassan MS, Mehmood $\mathrm{H}$ and Shahbaz M. Coal Consumption: An Alternate EnergyResource to Fuel Economic Growth in Pakistan (2013) Munich Personal RePEc Archive.

3. Mukherjee S and Borthakur PC. Effects of alkali treatment on ash and sulfur removal from Assam coal (2003) Journal Fuel Proc Tech 85: 93-101

4. Malkani MS et al., Coal resources of Pakistan: new coal fields (2016) J Sci Techl 5: 7-22.
5. Fu B et al. Emission and transformation behavior of minerals and hazardous trace elements (HTEs) during coal combustion in a circulating fluidized bed boiler (2018) J Environmental Pollution 242: 1950-1960. https://doi.org/10.1016/j.envpol.2018.07.066.

6. Khan M, Ahmad I and Akhtar G. Characterization and Comparative Study of Pakistani Coals by Liquids Adsorption Methods (2005) J Chemical Society of Pakistan 27: 580-584.

7. Wahid F et al. Characterization of Coal Samples from Dasal-I Coal Mine (2012) J Chemical Society of Pakistan 34: 1274-1278.

8. $\mathrm{Xu} \mathrm{M}$ et al. Status of trace element emission in a coal combustion process: a review (2003) J Energy and Environment, Fuel Processing Tech 85: 215: 237. https://doi.org/10.1016/s0378$\underline{3820(03) 00174-7 .}$.

9. Tian $\mathrm{HZ}$ et al. A Review of Key Hazardous Trace Elements in Chinese Coals: Abundance, Occurrence, Behavior during Coal Combustion and Their Environmental Impacts (2013) Energy Fuels 27: 601-614. https://doi.org/10.1021/ef3017305.

10. Ullah MS and Saleemi H. Desulfurization and Parametric Study of Bituminous Coal Via Froth Flotation Technique (2017) International J Advanced Biotechnology and Research (IJBR) 8: 237-245.

11. Krishnan MS. Classification of coal (1940) Geological Survey of India.

12. Malkani MS. A Review of Coal and Water Resources of Pakistan (2012) J of Sci Tech and Dev 31: 202-218.

13. Liu $\mathrm{G}$ et al. Enrichment and distribution of trace elements in Padhrar, Thar and Kotli coals from Pakistan: Comparison to coals from China with an emphasis on the elements distribution (2018) J Geochemical Exploration 185: 153-169.

14. Thomas RE et al. Coal resources of the Sonda coal field, Sindh Province (1993) Pakistan International J Coal Geology 23: 159191. https://doi.org/10.1016/0166-5162(93)90047-e. 